\title{
Interest Income Tax Evasion, the EU Savings Directive, and Capital Market Effects
}

\author{
TINA KLAUTKE \\ ALFONS J. WEICHENRIEDER
}

CESIFO WORKING PAPER NO. 2300

CATEGORY 1: PubliC FinANCE

MAY 2008
An electronic version of the paper may be downloaded
- from the SSRN website: Www.SSRN.com
- from the RePEc website: Www.RePEc.org
- from the CESifo website: www.CESifo-group.org/wp




\title{
Interest Income Tax Evasion, the EU Savings Directive, and Capital Market Effects
}

\begin{abstract}
The Savings Directive has been celebrated as a major political break-through in coordinating taxation in Europe. Against this background, the present paper evaluates the real-world effects of this directive. The directive has left a loophole by providing grandfathering (exemption from withholding tax) for some securities. In this paper we compare the pre-tax returns of exempt bonds and comparable taxable bonds. If working around the Savings Directive is difficult for tax evaders in Europe, then investors should be willing to pay a premium for bonds that are exempt from the withholding rate. Conversely, if such a premium is absent, then we may conclude that the supply of existing loopholes (exempt bonds included) is large enough to allow tax evaders to continue evasion at no additional cost. The findings of our study are in line with this latter interpretation.
\end{abstract}

JEL Code: H24.

Keywords: Savings Directive, interest taxation, tax capitalization, Austria, Belgium Luxembourg, Liechtenstein.

Tina Klautke

Johann Wolfgang Goethe University

Faculty of Economics and Business

Administration

60054 Frankfurt (Main)

Germany

t.klautke@econ.uni-frankfurt.de
Alfons J. Weichenrieder

Johann Wolfgang Goethe University

Faculty of Economics and Business

Administration

60054 Frankfurt (Main)

Germany

a.weichenrieder@em.uni-frankfurt.de

30. April 2008

We are grateful for helpful discussions with Ludwig Andorfer and Uwe Hassler. All remaining errors are ours. 


\section{INTRODUCTION}

In the EU, coordinated action in the area of direct taxation is difficult to achieve and few measures have been adopted in the past. A recent exception is the "Directive on taxation of savings income in the form of interest payments", more commonly known as the "Savings Directive" (European Community 2003/48/EC). The ultimate aim of this directive is to allow member states of the EU to tax interest income of resident individuals if they earn interest income abroad. Without cross-border coordination between states, a large portion of interest income earned abroad may be concealed by taxpayers and the taxation of interest becomes highly incomplete.

Against this background, the agreement on the Savings Directive has been celebrated as a major breakthrough. ${ }^{1}$ As of $1^{\text {st }}$ July 2005, the directive requires a member state A to electronically report to the country of residence B when an individual resident in B is paid interest income by a bank in A. An exception applies for Austria, Belgium and Luxembourg. For a (potentially indefinite) intermediate period, these member states are exempt from providing information exchange, unless the foreign investor consents. Instead, these countries have to levy a withholding tax on interest income paid to residents in other member states, $75 \%$ of which has to be forwarded to the relevant countries of residence, but without revealing the identity of the interest recipient. This agreement became effective only after equivalent arrangements have been negotiated with third countries (Andorra, Liechtenstein, Monaco, San Marino, and Switzerland) and overseas and associated territories, like the British Virgin Islands, the Turks and Caicos Islands, Guernsey, Jersey, the Isle of Man, and the Netherlands Antilles. From $1^{\text {st }}$ July 2005, the relevant withholding rate is $15 \%$. The directive 2003/48/EC (as revised by 2004/587/EC) provides for an increase to $20 \%$ in mid-2008 and to $35 \%$ in mid2011.

\footnotetext{
${ }^{1}$ See, e.g., Bundesministerium der Finanzen (2007, p. 51).
} 
An important question is whether the Savings Directive is only a political symbol and fig leaf or whether it has real world implications for the amount of taxable interest income evaded. Doubts about the effectiveness of the directive may arise since several loopholes obviously exist. For example, the Savings Directive applies to a narrow definition of interest income only. Most returns from investment funds are exempt, as are dividends on shares, income from life insurances, and derivatives. Further, despite remarkable success in striking agreements, the list of third countries that have cooperated with the EU in striking comparable agreements is certainly incomplete and a considerable number of non-European tax havens are still available for tax evasion. ${ }^{2}$ Eventually, even within Europe withholding taxes only apply to interest paid to private individuals, so the use of legal intermediate entities, as for example the Liechtenstein family foundations, which recently have received quite some attention, free banks from the obligation of applying the withholding tax.

So far, there is only limited evidence about the effectiveness of the Savings Directive. In 2006, Germany for example has received a total of $€ 144.5 \mathrm{~m}$ in forwarded withholding taxes from cooperating countries (Austria, Belgium, Luxembourg, and several non-EU countries) and the information provided on cross-border interest income by Germans covers some $€ 1.5 \mathrm{bn} .^{3}$ At the same time, it is unclear to what extent these figures indicate a reduction in interest income evasion. The reported income may simply refer to the portion of interest income that would have been filed by honest taxpayers even in the absence of the information exchange and similarly, the withholding taxes may apply to interest income that is reported in Germany, and where taxpayers take out a tax credit for withholding taxes paid abroad.

In this paper we study the availability of loopholes by measuring the cost that taxpayers are willing to incur to take advantage of a particular loophole provided by the savings directive. According to Article 15 of the directive, negotiable bonds that have been issued before $1^{\text {st }}$ March 2001 are exempt from the withholding tax as long as Austria, Belgium

\footnotetext{
${ }^{2}$ At the time of writing, talks with Singapore, Hong Kong and Macao have already been initiated. A detailed discussion on possible limitations of the directive provides the Expert Group on the Taxation of Savings (2007).

${ }^{3}$ Bundesministerium der Finanzen (2007).
} 
and Luxembourg use withholding taxes instead of providing information exchange. ${ }^{4}$ The preamble of the directive justifies this exception by the objective to avoid possible "market disruptions." This "grandfathering" of older bonds makes these securities the preferred choice for tax dodgers: in the absence of further taxation in the country of residence, these investors will prefer the bonds that are exempt from the withholding rates over bonds that are taxed or bonds that are deposited at banks in countries that provide information exchange.

The present paper investigates whether the securities that qualify for this grandfathering rule have experienced a decrease in pre-tax return that may reflect the additional demand of tax evaders. If other loopholes are costly, then dishonest taxpayers will be willing to accept a lower before tax return on grandfathered securities that allow avoidance of the withholding tax rate compared to securities that are subject to the withholding tax. Whether dishonest taxpayers who consider shifting towards grandfathered bonds indeed have to accept a gross return that falls short of bonds that do not qualify for grandfathering of course depends also on the magnitudes of supply and demand for the tax-favored bonds. In any case, absence of tax effects for the differential returns on grandfathered and nongrandfathered bonds should suggest that existing loopholes are wide enough to render the current version of the Savings Directive ineffective.

While there has been an extensive discussion of the Savings Directive among public finance economists, the question put forward in the present paper has to the best of our knowledge not been addresses in the literature. Previous discussions of the Savings Directive have focused on the question of whether it is better to have information exchange or a withholding tax (Huizinga and Nielsen 2003) and have discussed under what conditions voluntary information exchange may result (Eggert and Kolmar 2002).

The present paper is partly inspired by the studies that analyze the return differential of tax exempt municipal bonds and taxable state and federal bonds in the U.S. (see for examples

\footnotetext{
${ }^{4}$ The exemption is limited to interest income before $31^{\text {st }}$ December 2010. Another qualification for exemption from the withholding tax is that there were no further issues of the same security after $1^{\text {st }}$ March 2002 (Article 15(1), 2003/48/EC).
} 
Grinblatt and Titman 2002, Poterba 1989, and Gordon and Malkiel 1981). Due to the fact that the returns of municipal bonds are not subject to tax for US investors, the return of these bonds is empirically found to be smaller than the before tax return of other securities. In the present case, the tax effects may be less pronounced as bonds that fall under the grandfathering rule create a tax benefit to an arguably smaller group of taxpayers, those that are tax dodgers. Unlike in the U.S. case, institutional investors are not affected as the withholding tax (and the information exchange) is limited to the case of personal investors. Essentially, the question of whether the withholding tax is relevant for asset returns is therefore an empirical question.

\section{The Data Set}

In collecting our data set we started by considering a huge set of interest bearing securities that have been in circulation in mid-2007. The data set we started with contains all negotiable securities (in total 6,013) that at this date could be ordered via publicly owned banks (Sparkassen) in Germany. This compares to a total of 18,387 securities that were traded in Germany according to Deutsche Börse (2006). Among the 6,013 securities in our data set we identified 1,006 grandfathered bonds denominated in euro. In a next step we constructed pairs of twin bonds that ideally differ only in the fact that one part of each pair is grandfathered (i.e., not subject to the $15 \%$ withholding tax rate that according to the Savings Directive must be retained by Austria, Belgium and Luxembourg), while the other is not. While this necessarily implies that one part of each pair was issued earlier than the other one to receive preferential treatment under the grandfathering rule, we made sure that other characteristics of the pairs are comparable. In particular, we imposed the following restrictions. (i) Each pair must have been issued by the same institution or firm. (ii) To involve the same risk characteristics, both securities had to be denominated in the same currency. We decided to restrict our sample to pairs of twins issued in euro as this is the denomination European tax dodgers should have a preference for. (iii) To avoid comparisons of securities with stark 
diverging time horizons, difference in the remaining time to maturity (as of July $1^{\text {st }}$, 2007) was not allowed to exceed one year. (iv) Return information on both twins had to be available for at least two quarters prior to the introduction of the withholding rate. (v) Finally, price and return information for all twins had to be available from the Thompson Financial data base. A complete list of the securities in our sample is provided in the Appendix.

\section{Figure 1: Differences in maturity}

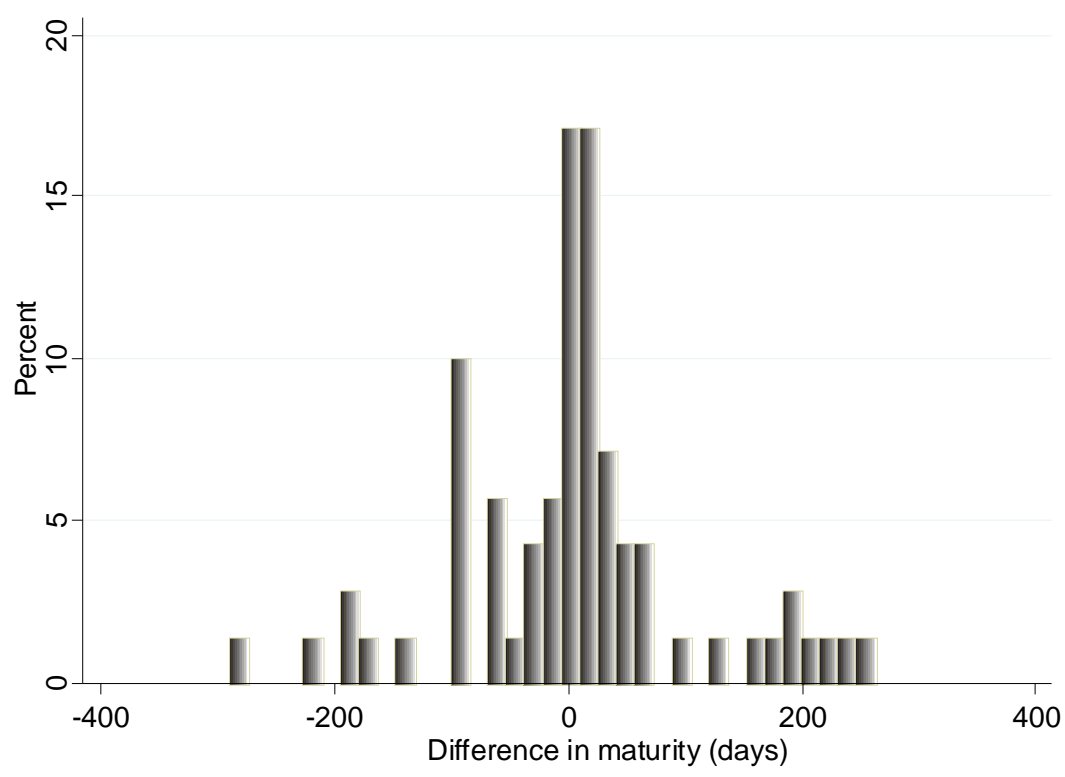

Annotation: The figure reports the difference in maturities. A negative difference implies that the remaining maturity of the grandfathered bond is longer.

These restrictions produced a set of 70 twins with 1,246 pairs of quarterly return information. Since securities that qualify for grandfathering are issued prior to March 2001 and we imposed the restriction of similar maturity, we are dependent on issuers who subsequent to the issue of a grandfathered bond have also given out a comparable bond with shorter maturity.

Figure 1 reports the differences in the maturity within twins, by counting the days that the maturity of the grandfathered bond exceeds the maturity of the twin. As can be seen, most differences in maturities lie in a 50 days band and the distribution is rather symmetric. This 
suggests that any yield curve effects, which may produce a systematic higher or lower yield for securities with a longer maturity, should not systematically influence the return difference among our pairs of twins.

\section{Evidence on Return Differences}

As mentioned in the introduction, if tax evaders happen to be the marginal traders of securities, then we would expect that tax exempt securities trade at a premium and pay a lower pre-tax return. More formally, let $r^{\text {gf }}$ be the pre-tax return of a grandfathered bond and $r^{\text {tw }}$ the return of its taxable twin. Then we would expect that a trader who cannot escape the withholding tax $t$, but can evade other taxes is indifferent if

$$
(1-t) r^{t w}=r^{g f} \text {, or } r^{t w}=r^{g f} /(1-t) .
$$

With a withholding rate of $15 \%$ we would have that the return of the taxable twin could be $17.6 \%=[1 /(1-15 \%)]-1$ higher than that of the grandfathered bond. Clearly, forward looking investors will not only consider the actual withholding tax, but will anticipate future taxes, leading to possible tax capitalization effects well ahead of the actual introduction. This calls for an account of the path that led to the directive and the grandfathering rule.

The first concrete proposals towards a withholding tax on cross-border interest in Europe was formulated in 1989 in Commission proposal COM (89) 60 final, which suggested a minimum withholding rate of $15 \%$, but without mentioning of grandfathering. Upon strong concerns about capital flight, the proposal was withdrawn in favor of COM (98) 295 final of $4^{\text {th }}$ June 1998. This revised proposal provided for a choice for member states to either introduce a withholding tax of $20 \%$ on cross-border interest paid to private individuals, or to introduce a system of information exchange with other member states. Again, the proposal contained no grandfathering rule for specific securities. In a next step the Commission formulated COM(2001) 400 final of $18^{\text {th }}$ July 2001, based on a basic agreement of the Council 
of November 2000. It favored the system of information exchange but allowed Austria, Belgium and Luxembourg a transition period of seven years during which they would not participate in information exchange but levy a withholding tax on interest. This revised proposal introduced the idea of grandfathering (i.e., exempting from withholding tax) securities issued before $1^{\text {st }}$ March 2001. In the aftermath of this proposal, the introduction of the withholding tax stayed very uncertain, as negotiations in the Council made clear that cooperation by third-countries outside the EU was crucial to buy the consent of several member states. ${ }^{5}$ The legislated directive of $3^{\text {rd }}$ June 2003 (Council Directive 2003/48/EC) introduced $1^{\text {st }}$ January 2005 as the date for the withholding tax of $15 \%$, but had the same proviso as the previous proposal: without ratification of similar agreements with Switzerland, Liechtenstein, San Marino, Monaco and Andorra the introduction of the withholding tax in Austria, Belgium and Luxembourg was not in sight. In principle, the same proviso continued to hold after directive 2004/587/EC had pushed back the introduction of the withholding tax to $1^{\text {st }}$ July 2005, but in a press release of $19^{\text {th }}$ July 2004 the Commission announced that an agreement with the required third-countries has been reached on all matters of substance.

From this historical account it is not entirely clear at what time the markets, if at all, should have priced in a differential between grandfathered and non-grandfathered bonds. In any case, if tax dishonest investors are marginal, then arbitrage considerations suggest that at least after July 2005 the pre-tax return of grandfathered bonds should have fallen below that of comparable other bonds.

Table 1 and Figure 2 give summary information on the empirical yield differences in our sample. As reported in Table 1, the overall mean return of grandfathered bonds, measured by the redemption yield, in our sample was 3.698\%. ${ }^{6}$ The mean yield for the twin securities was only 2.5 basis points lower and the difference between yields did not change for the returns from July 2005 onwards, when the Savings Directive was fully effective. Figure 2

\footnotetext{
${ }^{5}$ See Rehm (2003) for a detailed account of the history of the Savings Directive.

${ }^{6}$ Based on the security price in the respective quarter, the redemption yield calculates the return of an investor who buys the security and holds it until maturity.
} 
gives a more detailed picture over time by plotting the mean, the median, the $25^{\text {th }}$ centile and the $75^{\text {th }}$ centile for the return difference between the twin and the grandfathered bond. The number of pairs that enter in the calculation at each quarter is plotted against the right hand scale. A positive difference implies that the return was lower for the grandfathered security. Such a lower pre-tax return for the grandfathered security would be commensurate with a preference of investors for the tax advantage granted by the Savings Directive. However, if anything, the figure suggests that the difference in returns has decreased over time, which is the contrary of what we would expect when tax dodgers were the marginal investors driving the price differential between grandfathered and non-grandfathered bonds. The overall levels of return do not provide any evidence for capital market effects of the Savings Directive.

Something that has increased over time is the variation in the return spread as illustrated by Figure 3. While the standard deviation in the return spread was 6 basis points for the period July 2001 through July 2003, it increased to 16 basis points for the period October 2003 through October 2007 and the increase is statistically significant. This seems to suggest that the legislation of the Savings Directive may have led to increased trade and thereby to an increased volatility in the return differences between grandfathered and non-grandfathered bonds. The increase in the standard deviation jumped up shortly after legislation of the Council Directive 2003/48/EC in summer 2003. In the following econometric analysis we will more closely look at whether there are systematic differences in the relative return of grandfathered securities and their respective twins before June 2003 and thereafter by essentially applying a difference in difference approach. But rather than using the difference in returns for pairs of twins as the left hand variable, we use the ratio of returns, which reflects equation (1) above. 
Table 1: Summary returns statistics for 70 pairs in percent

\begin{tabular}{llllll}
\hline \hline Variable & $\begin{array}{l}\text { Obser- } \\
\text { vations }\end{array}$ & mean & median & min & max \\
quarterly return, grandfathered bonds & 1246 & 3.698 & 3.742 & 2.121 & 10.093 \\
quarterly return, taxable twin & 1246 & 3.663 & 3.699 & 1.903 & 10.073 \\
$r^{t w} / r^{g f}$ & 1246 & 0.991 & 0.998 & 0.583 & 1.395 \\
return, grandfathered bonds, post II/05 & 700 & 3.763 & 3.859 & 2.121 & 5.066 \\
quarterly return, taxable twin, post II/05 & 700 & 3.730 & 3.826 & 1.903 & 5.077 \\
$r^{t w} / r^{g f}$, post II/05 & 700 & 0.992 & 0.998 & 0.583 & 1.395 \\
\hline \hline
\end{tabular}

Annotation: The table reports the summary statistics on quarterly data of the redemption yield, which equals the internal rate of return if a bond is purchased at the going price and all future cash flows are taken into account.

Figure 2: Return differences between grandfathered bonds and their twins

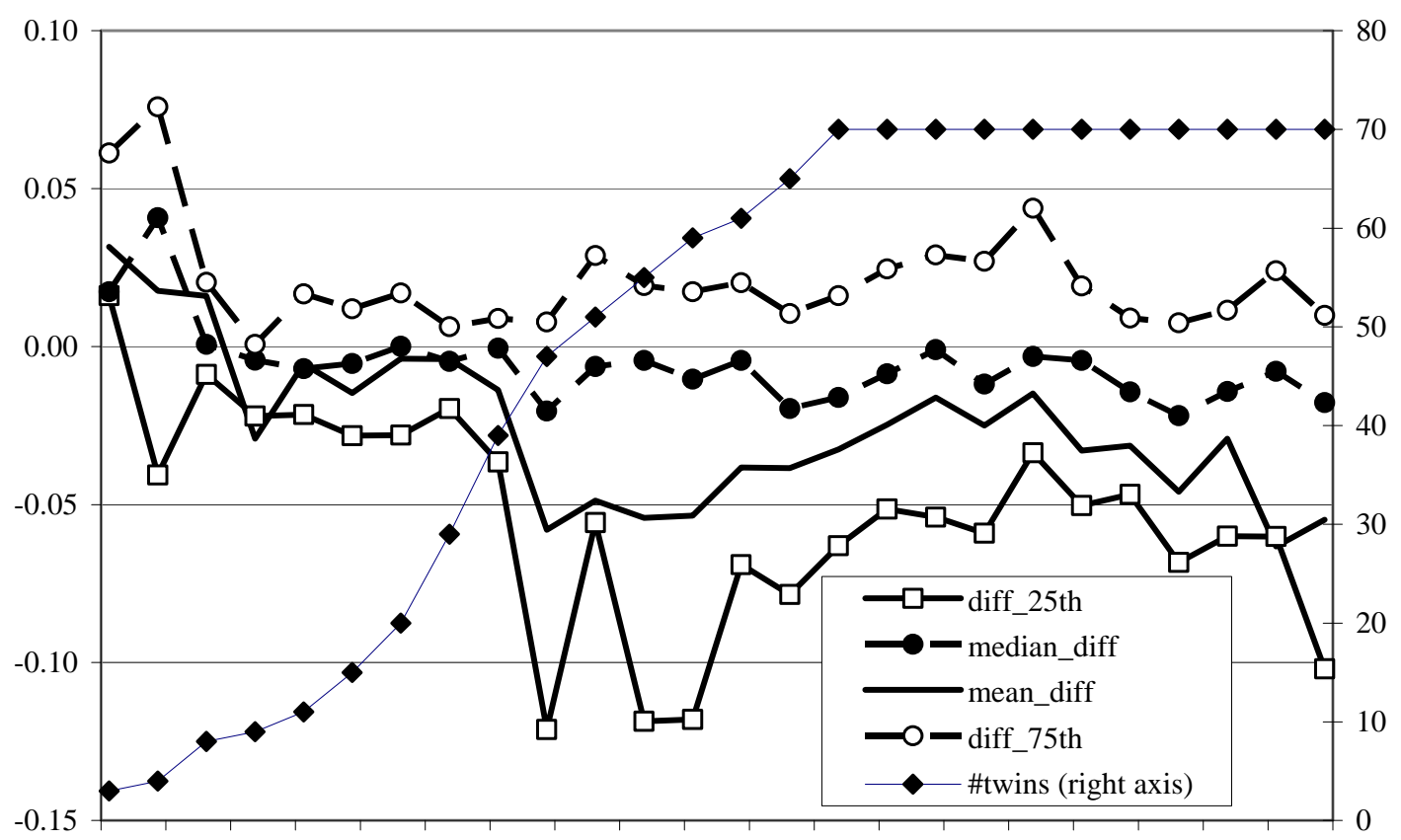

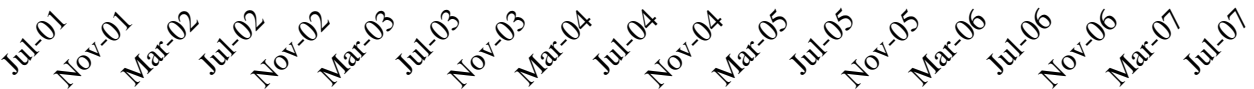

Annotation: For each pair of twins, the variable diff is defined as the pre-tax return (redemption yield) of the non-grandfathered security minus the pre-tax return of the grandfathered security. These differences in returns are plotted against the left scale for the $25^{\text {th }}$ centile, the median, the mean, and the $75^{\text {th }}$ centile for each quarter. The total number of pairs in each quarter is plotted on the right hand scale. 
Figure 3: Standard deviation of return ratio $\mathrm{r}^{\mathrm{tw}} / \mathrm{r}^{\mathrm{gf}}$

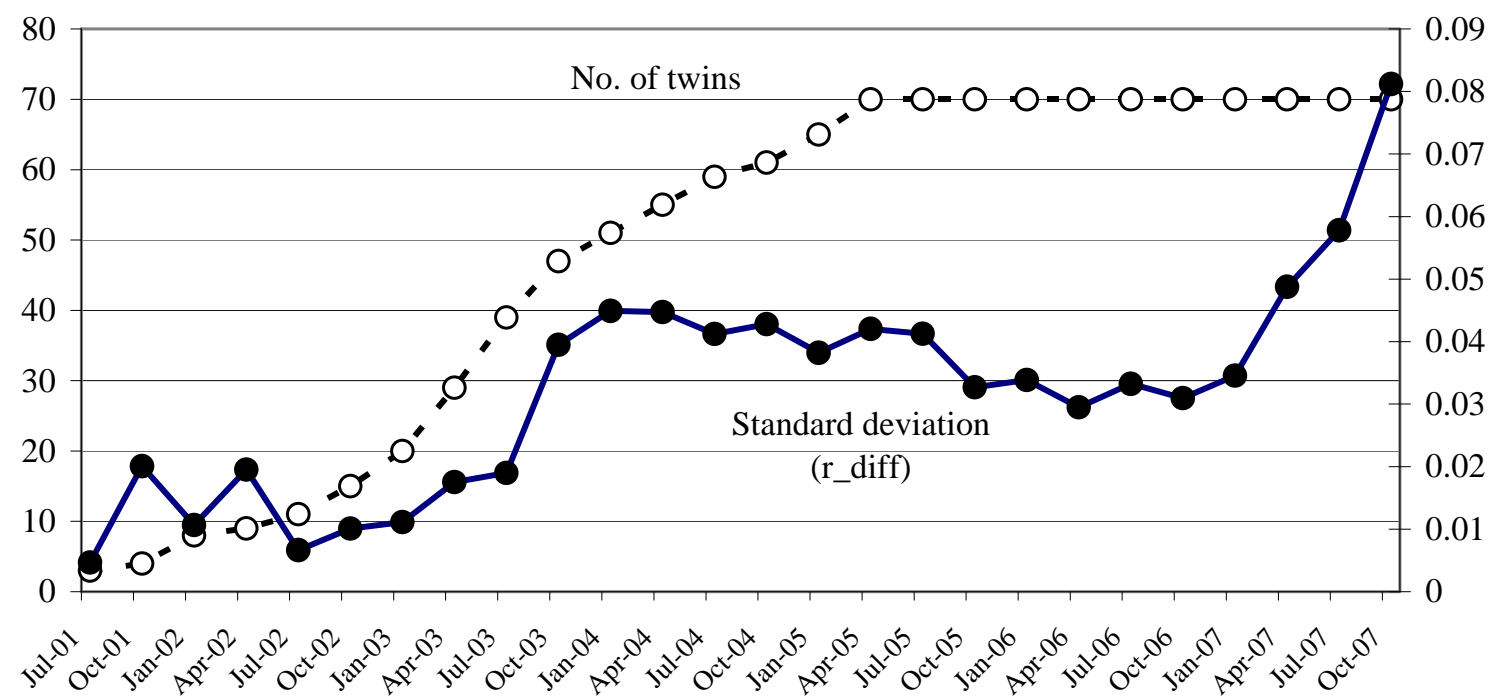

Annotation: The number of twins is plotted against the left scale and the standard deviation (r_diff $=r^{t w} / r^{g f}$ ) is plotted on the right hand scale.

For the empirical analysis we define three time windows. The dummy postII05 is marking return observations for July 2005 and thereafter (III/2005-IV2007). Since the announced withholding tax may have triggered anticipation effects we also created a dummy III03_II05 for quarterly observations between July 2003 (III/2003) and June 2005 (II/2005). The base periods, for which we presume that there was no anticipation of the withholding tax, are quarters before July 2003, i.e. III/2001 through II/2003.

Column (1) reports results from a simple OLS. While both time dummies for the post legislation periods are significant, they both have the wrong sign and are small in economic terms. The results are very similar in column (2), which reports results that have been derived by using fixed effects for each pair of twins. In both cases, the error terms show a high degree of serial correlation. Therefore, columns (3)-(7) report regressions with inclusion of two lags of the dependent variable. ${ }^{7}$ Inclusion of two lagged dependent variables makes the estimated

\footnotetext{
${ }^{7}$ While lagged dependent variables call for instrumental variable approaches, under rather mild assumptions, the bias in the estimates tends to be small with a long time horizon (see Green 2003). Arellano-Bond-type estimators have not been used because of the insufficient time variation of the exogenous variables, i.e. the dummies for the time windows.
} 
effect of the time window dummies smaller and insignificant. At the same time, it resolves the problem of first order autocorrelation in the errors. We also tried to include a third lag of the endogenous variable, but found this third lag to be insignificant. When we include lagged endogenous variables the F-test also allows to drop the dummies for each pair. The last three regressions therefore drop these dummies and we also use the acceptable restriction that the coefficients for III03_II05 and post_II05 are the same. Equations (5)-(7) use the dummy post_II03, which takes on the value one for observations from July 2003. Equation (6) tests whether the return ratio reacts differently for pairs of twins, depending on whether the emission volume of the grandfathered security is small compared to its taxable twin. If tax evaders are indeed looking for perfect substitutes of taxable securities, then the price reaction may be more pronounced if the supply of grandfathered bonds is small. The relevant variable is constructed as Volume* $\mathrm{d} 03=$ (Total emission of grandfathered bond in euro/total emission of taxable bond in euro)*post_II03. If after legislation of the directive, tax evaders demanded close substitutes, then we should expect that the estimated coefficient of Volume*d03 is negative. As reported in equation (6), there is no support for this. Finally, as Figure 2 has shown that our endogenous variable shows some outliers with extreme values up to 1.395 and as low as 0.583 , we also tested a robust estimation. Equation (7) reports the results derived by using least absolute values (LAV), a robust regression method which minimizes the sum of the absolute values of the residuals. This method estimates the effects of the explanatory variables on the conditional median of the dependent variable rather than the conditional mean. The results confirm the OLS results and suggest no capital market reactions to the Savings Directive.

Taken together, neither the observed return differences of taxable vs. exempt bonds as reported in Table 1, nor the difference in difference estimates reported in Table 2 are commensurate with an effect of the Savings Directive on bond returns. 
Table 2: Estimation results

\begin{tabular}{|c|c|c|c|c|c|c|c|}
\hline Variable & (1) OLS & (2) OLS & (3) OLS & (4) OLS & (5) OLS & (6) OLS & (7) LAV \\
\hline III03_II05 & $\begin{array}{l}-.011 \\
(0.00)^{* * *}\end{array}$ & $\begin{array}{l}-.003 \\
(0.26) \\
\end{array}$ & $\begin{array}{l}-.002 \\
(0.34) \\
\end{array}$ & $\begin{array}{l}-.002 \\
(0.29) \\
\end{array}$ & --- & --- & --- \\
\hline post_II05 & $\begin{array}{l}-.007 \\
(0.00)^{* * *}\end{array}$ & $\begin{array}{l}-.001 \\
(0.65) \\
\end{array}$ & $\begin{array}{l}-.002 \\
(0.32) \\
\end{array}$ & $\begin{array}{l}-.002 \\
(0.19)\end{array}$ & --- & --- & --- \\
\hline post_II03 & --- & --- & --- & --- & $\begin{array}{l}-.002 \\
(0.30) \\
\end{array}$ & $\begin{array}{l}-0.002 \\
(0.21) \\
\end{array}$ & $\begin{array}{l}-.001 \\
(0.33) \\
\end{array}$ \\
\hline r_diff_lag1 & --- & --- & $\begin{array}{l}.493 \\
(0.00)^{* * *}\end{array}$ & $\begin{array}{l}.430 \\
(0.00)^{* * *}\end{array}$ & $\begin{array}{l}.493 \\
(0.00)^{* * *}\end{array}$ & $\begin{array}{l}.490 \\
(0.00)^{* * *}\end{array}$ & $\begin{array}{l}.588 \\
(0.00)^{* * *}\end{array}$ \\
\hline r_diff_lag2 & --- & --- & $\begin{array}{l}.497 \\
(0.00)^{* * *}\end{array}$ & $\begin{array}{l}.508 \\
(0.01)^{* * *}\end{array}$ & $\begin{array}{l}.498 \\
(0.00)^{* * *}\end{array}$ & $\begin{array}{l}.492 \\
(0.00)^{* * *}\end{array}$ & $\begin{array}{l}.332 \\
(0.00)^{* * *}\end{array}$ \\
\hline Volume*d03 & --- & --- & --- & --- & --- & $\begin{array}{l}3.4 \mathrm{E}-04 \\
(0.28) \\
\end{array}$ & $\begin{array}{l}2.8 \mathrm{E}-04 \\
(0.19)\end{array}$ \\
\hline constant & $\begin{array}{l}.999 \\
(0.00)^{* * *}\end{array}$ & $\begin{array}{l}.984 \\
(0.00)^{* * *}\end{array}$ & $\begin{array}{l}0.012 \\
(0.82) \\
\end{array}$ & $\begin{array}{l}0.061 \\
(0.59) \\
\end{array}$ & $\begin{array}{l}.012 \\
(0.82) \\
\end{array}$ & $\begin{array}{l}.019 \\
(0.73) \\
\end{array}$ & $\begin{array}{l}0.081 \\
(0.00)^{* * *}\end{array}$ \\
\hline Fixed effects & no & yes & no & yes & no & no & no \\
\hline F-test FE & --- & $(0.00)^{* * *}$ & --- & $(0.52)$ & --- & --- & --- \\
\hline $\begin{array}{l}\text { linear } \\
\text { restriction } \\
\text { III03_II05 = } \\
\text { post_II05 }\end{array}$ & $(0.17)$ & $(0.39)$ & $(0.86)$ & $(0.72)$ & --- & --- & --- \\
\hline Observations & 1246 & 1246 & 1106 & 1106 & 1106 & 1106 & 1106 \\
\hline R2/pseudoR2 & $0.5 \%$ & $54 \%$ & $72 \%$ & $74 \%$ & $72 \%$ & $72 \%$ & $49 \%$ \\
\hline
\end{tabular}

Annotation: Endogenous variable: $r$ diff $=r^{t w} / r^{g f}$. P-values in brackets are calculated from robust standard errors in the case of OLS regressions, from bootstrap standard errors with 200 repetitions in the case of LAV. $* * *, * *, *$ indicate significance at the 1,5 , and 10 percent level, respectively. 


\section{Conclusions}

The Savings Directive has been celebrated as a major break-through in coordinating taxation in Europe. Against this background, the present paper evaluated the real-world effects of this directive. The directive has left one explicit loophole by providing grandfathering (exemption from withholding tax) for some securities. In this paper we have compared the pre-tax returns of these exempt bonds and comparable taxable bonds. If working around the Savings Directive is difficult for tax evaders in Europe, then investors should be willing to pay a premium for bonds that are exempt from the withholding rate. Conversely, if such a premium is absent, then we may conclude that the supply of existing loopholes (exempt bonds included) is large enough to allow tax evaders to continue evasion at negligible additional cost. The findings of our study are in line with this latter interpretation. This suggests that, at least so far, the Savings Directive is only a minor hassle for European savers looking for ways to work around interest income taxation. This stands in striking contrast to the considerable bureaucratic and political efforts that have been exerted to introduce the measures taken. As a caveat, it should be noted that grandfathering will end at December $31^{\text {st }}, 2010$. At least, this will close the loophole that has acted as a litmus test in the present study. 


\section{BIBLIOGRAPHY}

Bundesministerium der Finanzen. "Die EU-Richtlinie zur Besteuerung ausländischer Zinserträge." Monthly Report of the German Finance Ministry, October 2007.

Deutsche Börse. Deutsche Börse Factbook, 2006.

Eggert, Wolfgang and Kolmar, Martin. "Residence-based capital taxation in a small open economy: why information is voluntarily exchanged and why it is not." International Tax and Public Finance, 2002, 9(4), pp. 465-482.

Expert Group on the Taxation of Savings. Review of the operation of the Council Directive 2003/48/EC on taxation of income from savings. European Commission, Brussels, 000701।workingdoclen-05-08, 2007.

Gordon, Roger and Malkiel, Burton G. "Corporation finance," in Henry J. Aaron and Joseph A. Pechman, eds., How taxes affect economic behavior. Washington: Brookings Institution, 1981, pp. 131-198.

Green, William, Econometric Analysis. $5^{\text {th }}$ edition. Prentice-Hall, 2003.

Grinblatt, Mark and Titman, Sheridan. Financial markets and corporate strategy. $2^{\text {nd }}$ ed., McGraw-Hill, 2002.

Huizinga, Harry Pieter and Nielsen, Søren Bo. "Withholding taxes or information exchange: the taxation of international interest flows." Journal of Public Economics, 2003, 87(1), pp. 39-72.

Poterba, James M., "Tax reform and the market for tax-exempt debt", Regional Science and Urban Economics, 1989, 19(3), pp. 537-562.

Rehm, Hannes. "Die Zinsbesteuerung in der Europäischen Union", Discussion Paper, University of Hannover, 2003. 
Appendix: Sample of pairs of negotiable securities

\begin{tabular}{|c|c|c|c|c|c|}
\hline $\begin{array}{l}\text { ISIN: } \\
\text { Grandfathered }\end{array}$ & $\begin{array}{l}\text { ISIN: } \\
\text { Twin }\end{array}$ & Country & Emitter & $\begin{array}{l}\text { Expire date: } \\
\text { Grandfathered }\end{array}$ & $\begin{array}{l}\text { Expire date: } \\
\text { Twin }\end{array}$ \\
\hline ES0413211006 & ES0413211063 & Argentina & Bank & 1-Oct-09 & 3-Dec-09 \\
\hline DE0002298502 & DE0005517700 & Germany & Bank & 8-Aug-08 & 11-Jun-08 \\
\hline DE0002131042 & DE0001614584 & Germany & Bank & 2-Jun-10 & 18-Jun-10 \\
\hline BE0000262684 & BE0000298076 & Belgium & Government & 24-Dec-12 & 28-Sep-12 \\
\hline BE0000268749 & BE0000302118 & Belgium & Government & 29-Jul-08 & 28-Sep-08 \\
\hline BE0000282880 & BE0000306150 & Belgium & Government & 28-Mar-15 & 28-Sep-15 \\
\hline DE0002278058 & DE0002278538 & Germany & Bank & 16-Oct-08 & 20-Nov-08 \\
\hline DE0001240042 & DE0001240174 & Germany & Government & 28-May-10 & 2-Jun-10 \\
\hline DE0001240059 & DE0001240166 & Germany & Government & 16-Mar-09 & 10-Feb-09 \\
\hline DE0001240075 & DE0001240182 & Germany & Government & 24-Jan-11 & 7-Sep-11 \\
\hline DE0001135168 & DE0001135184 & Germany & Government & 4-Jan-11 & 4-Jul-11 \\
\hline XS0118237188 & XS0168860509 & USA & Bank & 1-Oct-10 & 21-May-10 \\
\hline DE0002330677 & DE0002738218 & Germany & Bank & 7-Apr-09 & 1-Dec-09 \\
\hline DE0002330826 & DE0003257135 & Germany & Bank & 30-Apr-08 & 1-Apr-08 \\
\hline DE0002330842 & DE0003118121 & Germany & Bank & 12-Mar-10 & 19-Mar-10 \\
\hline DE0002738200 & DE0002738226 & Germany & Bank & 1-Feb-11 & 6-Jun-11 \\
\hline DE0002474798 & DE000A0A2788 & Germany & Bank & 4-Mar-09 & 8-Sep-09 \\
\hline DE0002321155 & DE0001196442 & Germany & Bank & 19-Jun-08 & 17-Sep-08 \\
\hline DE0002596384 & DE000A0DRUN7 & Germany & Bank & 5-Aug-08 & 18-Aug-08 \\
\hline FR0000570780 & FR0000188690 & France & Government & 26-Dec-12 & 25-Oct-12 \\
\hline XS0118728756 & XS0173290148 & USA & Bank & 6-Oct-10 & 4-Aug-10 \\
\hline XS0124047431 & XS0156924051 & UK & Bank & 5-Feb-13 & 29-Oct-12 \\
\hline DE0001381531 & DE0001381770 & Germany & Government & 4-Jan-11 & 10-Jun-11 \\
\hline XS0098738056 & XS0147372949 & UK & Bank & 24-Jun-09 & 5-May-09 \\
\hline DE0002574142 & DE0001697134 & Germany & Bank & 11-Aug-08 & 26-Sep-08 \\
\hline DE0002574027 & DE000HBE0BQ8 & Germany & Bank & 22-Jan-08 & 11-Mar-08 \\
\hline DE0002574241 & DE000HBE0BA2 & Germany & Bank & 19-Jan-09 & 27-Feb-09 \\
\hline IT0001224309 & IT0003804850 & Italy & Government & 1-May-08 & 1-Feb-08 \\
\hline IT0001273363 & IT0003652077 & Italy & Government & 1-Мay-09 & 15-Apr-09 \\
\hline IT0001448619 & IT0003799597 & Italy & Government & 1-Nov-10 & 15-Jan-10 \\
\hline DE0002760790 & DE0002760915 & Germany & Bank & 17-Jun-13 & 4-Jul-13 \\
\hline DE0005881635 & DE0001609097 & Germany & Bank & 18-Oct-07 & 16-Oct-07 \\
\hline DE0007550857 & DE0007627044 & Germany & Bank & 12-Nov-07 & 12-Nov-07 \\
\hline DE0003412987 & DE0001261386 & Germany & Bank & 11-Dec-07 & 15-Dec-07 \\
\hline DE0003036380 & DE000A0A3RC8 & Germany & Bank & 7-Jan-08 & 17-Dec-07 \\
\hline DE0003892477 & DE0003116497 & Germany & Bank & 14-Jan-08 & 14-Jan-08 \\
\hline DE0003458998 & DE0008087933 & Germany & Bank & 13-Feb-08 & 4-Feb-08 \\
\hline DE0003454815 & DE000LBW1NL4 & Germany & Bank & 21-Apr-08 & 29-Apr-08 \\
\hline DE0003454971 & DE0003250882 & Germany & Bank & 13-May-08 & 8-May-08 \\
\hline DE0001237758 & DE0007153017 & Germany & Bank & 15-Sep-08 & 5-Sep-08 \\
\hline DE0003036091 & DE0001474351 & Germany & Bank & 27-Nov-08 & 28-Nov-08 \\
\hline DE0003035945 & DE0002912292 & Germany & Bank & 27-Nov-08 & 15-Dec-08 \\
\hline DE0003036604 & DE0007627093 & Germany & Bank & 15-Dec-08 & 15-Dec-08 \\
\hline DE0001023927 & DE0001618809 & Germany & Bank & 9-Jan-09 & 21-Jan-09 \\
\hline
\end{tabular}




\begin{tabular}{|c|c|c|c|c|c|}
\hline DE0003037214 & DE0006943582 & Germany & Bank & 4-Mar-09 & 30-Jan-09 \\
\hline DE0003517132 & DE000LBW1PS4 & Germany & Bank & 14-May-09 & 3-Jun-09 \\
\hline DE0003519922 & DE0007627051 & Germany & Bank & 4-Dec-09 & 14-Dec-09 \\
\hline DE0001162691 & DE0007935769 & Germany & Bank & 21-Jan-10 & 22-Jan-10 \\
\hline DE0001023810 & DE0007266793 & Germany & Bank & 6-Jul-10 & 30-Jul-10 \\
\hline DE0006276306 & DE000A0A24C6 & Germany & Bank & 14-Feb-11 & 10-Mar-11 \\
\hline DE0002268778 & DE0001663656 & Germany & Bank & 30-Oct-08 & 1-Sep-08 \\
\hline DE0002984622 & DE0002984895 & Germany & Bank & 2-Oct-08 & 7-Jul-08 \\
\hline DE0002985884 & DE0002983194 & Germany & Bank & 6-Oct-08 & 3-Mar-08 \\
\hline DE0002987575 & DE0002983301 & Germany & Bank & 1-Jul-08 & 17-Jan-08 \\
\hline DE0002989563 & DE0003115689 & Germany & Bank & 16-Мау-08 & 23-May-08 \\
\hline DE0002989753 & DE0007266264 & Germany & Bank & 1-Sep-08 & 28-Feb-08 \\
\hline DE0002674686 & DE0007691503 & Germany & Bank & 26-Nov-08 & 22-Dec-08 \\
\hline NL0000102192 & NL0000102309 & Netherlands & Government & 15-Apr-10 & 15-Jan-10 \\
\hline DE0001590818 & DE0001590867 & Germany & Government & 19-Jan-09 & 8-Oct-09 \\
\hline DE0003097077 & DE0007243750 & Germany & Government & 6-Dec-10 & 15-Feb-11 \\
\hline DE0001595585 & DE0001469104 & Germany & Government & 18-Jun-10 & 30-Jun-10 \\
\hline DE0001595668 & DE0001691764 & Germany & Government & 19-Jan-10 & 13-Aug-10 \\
\hline DE0001735918 & DE0007169963 & Germany & Government & 22-Jan-08 & $15-F e b-08$ \\
\hline DE0003074589 & DE0005520407 & Germany & Bank & 9-Apr-08 & 30-Apr-08 \\
\hline DE0003074787 & DE0008317629 & Germany & Bank & 1-Sep-08 & 30-Sep-08 \\
\hline DE0003071312 & DE0001114072 & Germany & Bank & 22-Dec-08 & 22-Dec-08 \\
\hline DE0003071916 & DE0003077137 & Germany & Bank & 7-Sep-09 & 2-Nov-09 \\
\hline DE0001788974 & DE0001789030 & Germany & Government & 22-Nov-10 & 25-Aug-10 \\
\hline DE0001785640 & DE0001786481 & Germany & Government & 6-Mar-08 & 16-Apr-08 \\
\hline ES0000012064 & ES0000012882 & Spain & Government & 30-Jul-09 & 31-Jan-09 \\
\hline
\end{tabular}




\section{CESifo Working Paper Series}

for full list see www.cesifo-group.org/wp

(address: Poschingerstr. 5, 81679 Munich, Germany, office@cesifo.de)

2237 Heinrich W. Ursprung and Christian Wiermann, Reputation, Price, and Death: An Empirical Analysis of Art Price Formation, March 2008

2238 Hans Fehr and Christian Habermann, Private Retirement Savings in Germany: The Structure of Tax Incentives and Annuitization, March 2008

2239 Joseph Francois and Ian Wooton, Market Structure and Market Access, March 2008

2240 Hiroyuki Kasahara and Beverly Lapham, Productivity and the Decision to Import and Export: Theory and Evidence, March 2008

2241 Gary E. Bolton and Axel Ockenfels, Does Laboratory Trading Mirror Behavior in Real World Markets? Fair Bargaining and Competitive Bidding on EBay, March 2008

2242 Atsushi Oshima, B. Ravikumar and Raymond Riezman, Entrepreneurship, Organization Capital and the Evolution of the Firm, March 2008

2243 Walter Krämer and Sebastian Schich, Large-Scale Disasters and the Insurance Industry, March 2008

2244 Leif Danziger, Adjustment Costs, Inventories and Output, March 2008

2245 Anne van Aaken, Lars P. Feld and Stefan Voigt, Power over Prosecutors Corrupts Politicians: Cross Country Evidence Using a New Indicator, March 2008

2246 Hans-Christian Heinemeyer, Max-Stephan Schulze and Nikolaus Wolf, Endogenous Borders? The Effects of New Borders on Trade in Central Europe 1885-1933, March 2008

2247 Johannes Becker and Clemens Fuest, Tax Competition - Greenfield Investment versus Mergers and Acquisitions, March 2008

2248 Giorgio Bellettini and Hubert Kempf, Why not in your Backyard? On the Location and Size of a Public Facility, March 2008

2249 Jose Luis Evia, Roberto Laserna and Stergios Skaperdas, Socio-Political Conflict and Economic Performance in Bolivia, March 2008

2250 Bas Jacobs and A. Lans Bovenberg, Optimal Taxation of Human Capital and the Earnings Function, March 2008

2251 Jan-Egbert Sturm and Timo Wollmershäuser, The Stress of Having a Single Monetary Policy in Europe, March 2008 
2252 Guido Schwerdt, Labor Turnover before Plant Closure: ‘Leaving the Sinking Ship’ vs. 'Captain Throwing Ballast Overboard', March 2008

2253 Keith E. Maskus and Shuichiro Nishioka, Development-Related Biases in Factor Productivities and the HOV Model of Trade, March 2008

2254 Jeremy Edwards and Sheilagh Ogilvie, Contract Enforcement, Institutions and Social Capital: the Maghribi Traders Reappraised, March 2008

2255 Imed Drine and Christophe Rault, Purchasing Power Parity for Developing and Developed Countries. What can we Learn from Non-Stationary Panel Data Models?, March 2008

2256 Scott Alan Carson, Health, Wealth and Inequality: a Contribution to the Debate about the Relationship between Inequality and Health, March 2008

2257 C.A.E. Goodhart, The Regulatory Response to the Financial Crisis, March 2008

2258 Stefan Bauernschuster, Oliver Falck and Stephan Heblich, The Impact of Continuous Training on a Firm's Innovations, March 2008

2259 Michael Grimm and Stephan Klasen, Geography vs. Institutions at the Village Level, March 2008

2260 Fwu-Ranq Chang, Property Insurance, Portfolio Selection and their Interdependence, March 2008

2261 J. Atsu Amegashie and Marco Runkel, The Paradoxes of Revenge in Conflicts, March 2008

2262 Hans Jarle Kind, Marko Koethenbuerger and Guttorm Schjelderup, Efficiency Enhancing Taxation in Two-sided Markets, March 2008

2263 M. Hashem Pesaran, Til Schuermann and L. Vanessa Smith, Forecasting Economic and Financial Variables with Global VARs, March 2008

2264 Volker Grossmann, Entrepreneurial Innovation and Sustained Long-run Growth without Weak or Strong Scale Effects, March 2008

2265 Robert S. Chirinko and Huntley Schaller, The Irreversibility Premium, March 2008

2266 Andrea Galeotti and José Luis Moraga-González, Platform Intermediation in a Market for Differentiated Products, April 2008

2267 Torben M. Andersen and Michael Svarer, The Role of Workfare in Striking a Balance between Incentives and Insurance in the Labour Market, April 2008

2268 Harald Badinger, Cyclical Fiscal Policy, Output Volatility, and Economic Growth, April 2008 
2269 Thomas Aronsson and Erkki Koskela, Outsourcing and Optimal Nonlinear Taxation: A Note, April 2008

2270 Gary E. Bolton, Claudia Loebbecke and Axel Ockenfels, How Social Reputation Networks Interact with Competition in Anonymous Online Trading: An Experimental Study, April 2008

2271 Nikolaus Wolf, Scylla and Charybdis. Explaining Europe’s Exit from Gold, January 1928 - December 1936, April 2008

2272 Michael Funke and Marc Gronwald, The Undisclosed Renminbi Basket: Are the Markets Telling us something about where the Renminbi - US Dollar Exchange Rate is Going?, April 2008

2273 Thor Olav Thoresen and Annette Alstadsæter, Shifts in Organizational Form under a Dual Income Tax System, April 2008

2274 Helge Berger and Volker Nitsch, Too many Cooks? Committees in Monetary Policy, April 2008

2275 Yin-Wong Cheung and Eiji Fujii, Deviations from the Law of One Price in Japan, April 2008

2276 Michael S. Michael, Sajal Lahiri and Panos Hatzipanayotou, Integrated Reforms of Indirect Taxes in the Presence of Pollution, April 2008

2277 Bas Jacobs, Is Prescott Right? Welfare State Policies and the Incentives to Work, Learn and Retire, April 2008

2278 Burkhard Heer and Alfred Maußner, Value Function Iteration as a Solution Method for the Ramsey Model, April 2008

2279 Jarko Fidrmuc and Christa Hainz, Integrating with their Feet: Cross-Border Lending at the German-Austrian Border, April 2008

2280 Kristof Dascher and Alexander Haupt, The Political Economy of Regional Integration Projects at Borders where Rich and Poor Meet: The Role of Cross-Border Shopping and Community Sorting, April 2008

2281 Katrin Assenmacher-Wesche and M. Hashem Pesaran, A VECX* Model of the Swiss Economy, April 2008

2282 Christophe Rault, Robert Sova and Ana Maria Sova, Modeling International Trade Flows between CEEC and OECD Countries, April 2008

2283 Timo Boppart, Josef Falkinger, Volker Grossmann, Ulrich Woitek and Gabriela Wüthrich, Qualifying Religion: The Role of Plural Identities for Educational Production, April 2008 
2284 Armin Falk, David Huffman and W. Bentley MacLeod, Institutions and Contract Enforcement, April 2008

2285 Axel Dreher and Stefan Voigt, Does Membership in International Organizations Increase Governments' Credibility? Testing the Effects of Delegating Powers, April 2008

2286 Xavier Freixas and Bruno M. Parigi, Lender of Last Resort and Bank Closure Policy, April 2008

2287 Regina Dionisius, Samuel Muehlemann, Harald Pfeifer, Günter Walden, Felix Wenzelmann and Stefan C. Wolter, Cost and Benefit of Apprenticeship Training - A Comparison of Germany and Switzerland, April 2008

2288 Francesco Daveri and Cecilia Jona-Lasinio, Off-Shoring and Productivity Growth in the Italian Manufacturing Industries, April 2008

2289 Mikael Priks, Do Surveillance Cameras Affect Unruly Behavior? A Close Look at Grandstands, April 2008

2290 Marianna Belloc and Daniela Federici, A Two-Country NATREX Model for the Euro/Dollar, April 2008

2291 Nicolas Treich, The Value of a Statistical Life under Ambiguity Aversion, April 2008

2292 J. Atsu Amegashie, Socially-Tolerable Discrimination, April 2008

2293 M. Hashem Pesaran and Andreas Pick, Forecasting Random Walks Under Drift Instability, April 2008

2294 Steven Brakman, Gus Garita, Harry Garretsen and Charles van Marrewijk, Unlocking the Value of Cross-Border Mergers and Acquisitions, May 2008

2295 Eric O’N. Fisher and Kathryn G. Marshall, The Structure of the American Economy, May 2008

2296 Claudia M. Buch and Martin Schlotter, Regional Origins of Employment Volatility: Evidence from German States, May 2008

2297 Helmuth Cremer, Philippe De Donder, Dario Maldonado and Pierre Pestieau, Taxing Sin Goods and Subsidizing Health Care, May 2008

2298 Reinhilde Veugelers and Frederick van der Ploeg, Reforming European Universities: Scope for an Evidence-Based Process, May 2008

2299 Jon H. Fiva and Lars J. Kirkebøen, Does the Housing Market React to New Information on School Quality?, May 2008

2300 Tina Klautke and Alfons J. Weichenrieder, Interest Income Tax Evasion, the EU Savings Directive, and Capital Market Effects, May 2008 